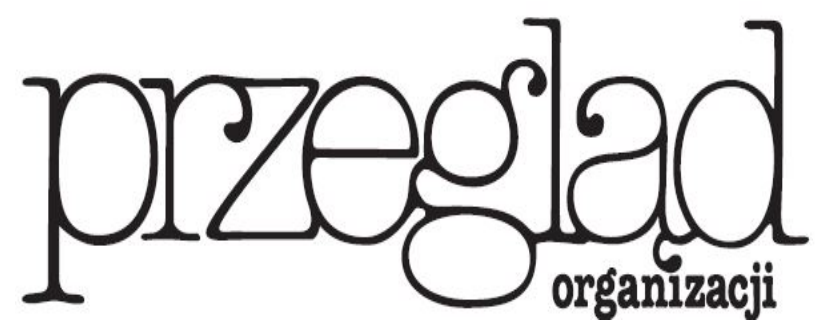

Miesięcznik TNOiK

Założył Karol Adamiecki w 1926 r.

\title{
ZASOBOWA TEORIA PRZEDSIĘBIORSTWA I KONCEPCJA LOGIKI USŁUGOWEJ W ŚWIETLE PODEJŚCIA RELACYJNEGO W ZARZACDZANIU
}

https://doi.org/10.33141/po.2019.01.03

\section{Bartosz Deszczyński}

\section{Wprowadzenie}

$\mathbf{Z}$ arówno zasobowa teoria przedsiębiorstwa (ang. Resource-Based View - RBV), jak i koncepcja logiki usługowej (ang. Service-Dominant Logic - SDL) cieszą się niesłabnącym zainteresowaniem teoretyków i praktyków zarządzania (Gummesson, 2017; Payne, Frow, 2017; Vargo, Lusch, 2017). Mimo względnej prostoty ich głównych założeń, brakuje jednoznacznych wskazówek do ich rzeczywistego zastosowania w praktyce biznesowej. Ponadto funkcjonują one niejako obok siebie, choć każda $\mathrm{z}$ nich na przyjętym poziomie ogólności pretenduje do wyjaśnienia źródeł sukcesu rynkowego przedsiębiorstw. W prezentowanym artykule, na gruncie epistemologicznych dociekań, podjęto próbę zbadania synergicznych powiązań pomiędzy RBV i SDL, posługując się przy tym terminologią i instrumentarium zaczerpniętymi $\mathrm{z}$ podejścia relacyjnego $\mathrm{w}$ zarządzaniu przedsiębiorstwem (PRZP). Postawiono przy tym tezę, iż PRZP może odegrać rolę łącznika pomiędzy RBV i SDL, prowadząc do czytelniejszego powiązania ich założeń teoretycznych z konkretnymi wyzwaniami, przed którymi stoją menedżerowie. W konsekwencji przyjęto założenie krzyżowania się czy wręcz możliwości integracji wszystkich trzech paradygmatów w ramach względnie
Przegląd Organizacji, Nr 1 (948), 2019, ss. 19-26 www.przegladorganizacji.pl @Towarzystwo Naukowe Organizacji i Kierownictwa (TNOiK) spójnej struktury pojęciowej. Stąd oryginalność tej pracy nie wynika ze stworzenia nowej teorii ad hoc, ale raczej $\mathrm{z}$ dążenia na drodze dedukcji do zwiększenia siły objaśniania rzeczywistości przez RBV, SDL i PRZP jako wzajemnie dopełniających się koncepcji, zarówno na płaszczyźnie teoretycznej, jak i projektowo-wdrożeniowej.

Procedura badawcza obejmowała w pierwszym rzędzie przegląd wybranych pozycji literaturowych ukierunkowany na syntetyczne zebranie poglądów na temat trzech analizowanych teorii, pochodzących od cieszących się powszechnym uznaniem polskich i zagranicznych teoretyków z zakresu zarządzania strategicznego przedsiębiorstwem. Rozpoczęto zatem od przywołania wskazywanych w literaturze głównych obszarów problematycznych dla RBV i SDL. Dalej podjęto próbę opisu funkcjonowania przedsiębiorstwa według, przedstawianych tym razem łącznie, podstawowych założeń RBV i SDL. Opis te zrodził kolejne pytania, na które zaproponowano znalezienie odpowiedzi z pomocą PRZP. Ostatecznie doprowadziło to do osiągnięcia celu artykułu w postaci sformułowania propozycji ogólnego modelu funkcjonowania przedsiębiorstwa $\mathrm{z}$ wykorzystaniem dorobku wszystkich trzech teorii jednocześnie ${ }^{1}$. 


\section{Pułapki paradygmatu zasobowego}

$\mathbf{R}$ BV to dość intuicyjna teoria. W dwóch prostych krokach wiąże ona rynkowe powodzenie przedsiębiorstwa $\mathrm{z}$ osiągnięciem przez nie przewagi konkurencyjnej, której źródłem są posiadane przez przedsiębiorstwo kluczowe zasoby (Barney, 1991). Koncepcja kluczowych, heterogenicznych zasobów przedsiębiorstwa stała się inspiracją do rozwoju perspektywy endogenicznej w zarządzaniu strategicznym zdominowanej do tej pory przez szkołę pozycyjną (Porter, 1979). To entuzjastyczne przyjęcie początkowo przesłoniło pewne problematyczne, jak się okazało, uproszczenia w podstawowych założeniach RBV, które do dzisiaj stanowią wyzwanie dla teoretyków i praktyków zarządzania (Obłój, 2007, s. 7-8):

- heterogeniczność zasobów ma prowadzić do osiągnięcia homogenicznej przewagi konkurencyjnej,

- osiągnięcie przewagi konkurencyjnej ma automatycznie zapewnić sukces rynkowy.

Zgodnie $\mathrm{z}$ oryginalnymi założeniami RBV, przewaga konkurencyjna traktowana jest $\mathrm{w}$ kategoriach zero-jedynkowych. Albo przedsiębiorstwo (korzystając z kluczowych zasobów) ją posiada, albo (będąc ich pozbawionym) nie. Wydaje się jednak, że niezmiernie rzadko zachodzi sytuacja, w której przedsiębiorstwo dysponuje w tym samym czasie nadzwyczaj cennymi zasobami w każdej dziedzinie swojej działalności. Bardziej prawdopodobna jest sytuacja, w której przedsiębiorstwo lepiej radzi sobie w wybranych obszarach, w innych zaś gorzej (Ray i in., 2004). Co więcej, taka „totalna” przewaga konkurencyjna musiałaby oznaczać, że proces izolacji kluczowych zasobów doprowadził do całkowitej autarkizacji przedsiębiorstwa (Wernerfelt, 2016, p. 301). Takie założenie jest być może atrakcyjne $\mathrm{z}$ punktu widzenia elegancji formalnej teorii, jednak nie ma ono znaczenia dla praktyki gospodarczej. Nie uwzględnia ono bowiem wpływu czynników zewnętrznych ograniczających autonomię przedsiębiorstwa w realizacji jego własnych celów, np. istnienia powiązań sieciowych pomiędzy firmami (Håkansson i in., 2009).

Rezygnując z zero-jedynkowej wizji przewagi konkurencyjnej, pojawia się jednak pytanie o sposoby wykorzystania częściowej przewagi konkurencyjnej w procesach rynkowych. Na przykład opanowanie skomplikowanej technologii nie oznacza jeszcze, że przedsiębiorstwo będzie potrafiło przekonać do jej walorów swoich kontrahentów. Dylemat ten częściowo rozwiązuje wprowadzenie koncepcji dynamicznych zdolności (kompetencji, umiejętności) (Hamel, 2002), objawiających się m.in. poprzez pozyskiwanie, alokowanie i wykorzystanie różnych rodzajów zasobów przedsiębiorstwa i skuteczne plasowanie na rynku zbudowanej na ich podstawie oferty. Wraz z jej upowszechnieniem zaczęły się jednak pojawiać kolejne pytania, m.in. w jaki sposób owe zdolności są tworzone czy aktywowane. Podobna dyskusja toczyła się m.in. na łamach Przeglądu Organizacji (Krupski, 2012; Obłój, 2007; Zakrzewska-Bielawska, 2013). Ten wstępny etap rozważań nad RBV zakończy jednak na razie konstatacja, że teoria ta koncentruje uwagę na wstępnych uwarunkowaniach koniecznych do osiągnięcia przewagi konkurencyjnej i jej utrzymania, ale jej pozytywistyczne założenia nie dają potwierdzonych empirycznie rekomendacji użytecznych w praktyce biznesowej przedsiębiorstw (Bratnicki, 2012; Czakon, 2010).

\section{Pułapki logiki usługowej}

C DL zajmuje znaczące miejsce $\mathrm{w}$ teorii marketingu $\checkmark$ usług. Podstawy koncepcji przedstawione w 2004 r. przez S.L. Vargo i R.F. Luscha łączą sukces rynkowy przedsiębiorstwa $\mathrm{z}$ umiejętnością oferowania klientom istotnej dla nich wartości. Co więcej, za podstawowego kreatora wartości S.L.Vargo i R.F. Lusch uznali samego klienta, mimo że głównym dostawcą zasobów użytecznych w tym procesie pozostaje przedsiębiorstwo (2004). Według nich, może ono pomóc klientowi $\mathrm{w}$ ich aktywizacji, dopiero wówczas stając się współkreatorem wartości, czego efektem jest zwiększenie użyteczności proponowanej oferty (Vargo, Lusch, 2008). Ogólna rekomendacja SDL jest zatem, można by rzec, genialnie prosta: przedsiębiorstwa powinny koncentrować swoją uwagę na klientach, a nie na sobie.

Autorzy stosują ją również do przedsiębiorstw produkcyjnych. Idąc za logiką usługową, z dostawców gotowych dóbr fizycznych powinny one przekształcić się we współtwórców końcowych wrażeń klientów z ich użytkowania. Tego rodzaju klientyzacja produkcji ma być niezawodnym sposobem na wyróżnienie oferty i zmianę roli przedsiębiorstwa $\mathrm{z}$ dostawcy na partnera (Grönroos, 2015; Vargo, Lusch, 2004).

Podobnie jednak jak RBV, tak i SDL nieobce są problemy definicyjne, a formułowane recepty dla praktyki gospodarczej obejmują najbardziej abstrakcyjną część rozważań strategicznych. Kwestie, które należałoby podnieść w tym artykule, to następujące założenia logiki usługowej (Vargo, Lusch, 2016, s. 8):

- wszystkie rynki mają charakter usługowy,

- współtworzenie wartości to wszechobecny proces rynkowy.

Fragmentaryzacja procesu produkcyjnego, outsourcing, offshoring i technologie informacyjne wzmacniają i tak już kluczową rolę usług w światowej gospodarce (Lovelock, Patterson, 2015). Wzrostu znaczenia sektora usług (services economy) nie można jednak w pełni utożsamiać ze zjawiskiem serwicyzacji gospodarki (service(-) economy). Serwicyzacja w ujęciu SDL oznacza bowiem nie tylko generowanie wartości poprzez oferowanie usług. Musi to być jednocześnie proces uwzględniający współużytkowanie zasobów partnerów, czego efektem jest pojawienie się dodatkowych korzyści dla obu stron (Vargo, Lusch, 2008, s. 7). Pełne przyjęcie logiki usługowej może zatem stanowić problem nie tylko $\mathrm{w}$ tradycyjnych branżach produkcyjnych, ale również w przypadku usługodawców. Wymaga ono aktywnego zaangażowania obu stron w proces kreowania wartości, przy czym z założenia stroną inicjującą zacieśnienie współpracy będzie zwykle przedsiębiorstwo. W wielu branżach bardzo trudno jest jednak pozyskać uwagę klienta, a co dopiero mówić o ścisłej współpracy. Dobrym tego przykładem może być 
proces zakupu materiałów biurowych przez firmy lub anonimowy zwykle proces zakupu dóbr pierwszej potrzeby przez klientów indywidualnych.

W swojej publikacji S.L. Vargo i R.F. Lusch (2016, s. 8-9) przyznają, że co prawda koprodukcja (będąca zaawansowaną formą współpracy z klientem) jest względnie rzadkim zjawiskiem, to jednak termin współtworzenie wartości należy traktować jako kategorię ekonomii pozytywnej, ponieważ w warunkach specjalizacji i współzależności „wartość jest zawsze współtworzona”. Dalej wspomniani autorzy rozwijają swą myśl, twierdząc, że: „Tworzenie wartości nie zachodzi za sprawą pojedynczego klienta lub innego podmiotu, ani też pomiędzy przedsiębiorstwami i ich klientami, ale $\mathrm{w}$ wielowymiarowym układzie zróżnicowanych podmiotów. Stąd, przynajmniej w wyspecjalizowanych ekosystemach ludzkich (a zapewne i zwierzęcych), wartość nie powstaje zupełnie indywidualnie, ani też $\mathrm{w}$ układach dualnych, ale raczej $\mathrm{w}$ procesie współużytkowania zasobów dostarczanych z wielu źródeł, w tym jakichkolwiek podmiotów prywatnych i publicznych mających kontakt z rynkiem" (Vargo, Lusch, 2016, s. 9).

Trudno sobie wyobrazić, jak przedsiębiorstwa usiłujące zachęcić swoich klientów do współtworzenia wartości, miałyby skorzystać z takiej definicji. Przyjęcie optyki rozszerzającej, można by rzec, w totalny sposób logikę usługową na całą gospodarkę, raczej rozmywa SDL, czyniąc tę koncepcję zbyt abstrakcyjną, aby mogła być użyteczna w poszukiwaniu odpowiedzi na pytanie o źródło pochodzenia wartości (Grönroos, Voima, 2013). Uznając wysoką złożoność ekosystemów usługowych, nie można jednak zapominać, że w naukach o zarządzaniu równie ważne co teorie ogólnie wyjaśniające rzeczywistość są teorie ją operacjonalizujące (Moss Kanter, 2011). W tym kontekście kluczowe wydaje się właśnie dociekanie, w jaki sposób w praktyce biznesowej współkreowana jest wartość. W dalszej części artykułu podjęto próbę zwięzłego przedstawienia tego zagadnienia $\mathrm{z}$ wykorzystaniem podejścia relacyjnego $\mathrm{w}$ zarządzaniu przedsiębiorstwem traktowanego jako swoistego łącznika RBV i SDL.

\section{Funkcjonowanie przedsiębiorstwa według RBV i SDL}

$\mathbf{Z}$ godnie z podstawowym założeniem RBV, każde przedsiębiorstwo posiada zasoby. Część z nich ma kluczowe znaczenie, co czyni je potencjalnym składnikiem oferty charakteryzującej się dużą użytecznością dla jej odbiorców i jednocześnie wyróżnia się heterogenicznością. Ta ich cecha zmniejsza prawdopodobieństwo, że (przynajmniej przez jakiś czas) wystąpią w tej samej konfiguracji $\mathrm{w}$ innym przedsiębiorstwie. Zasoby te określa się skrótem VRIO (valuable, rare, inimitable, organized). $\mathrm{Z}$ natury rzeczy trudno jest je pozyskać na drodze pojedynczej transakcji, jak również odtworzyć autonomicznie, gdyż byłby to zbyt długotrwały proces. Są to bowiem najczęściej zasoby niematerialne bezpośrednio lub pośrednio powiązane z pracownikami i ich wiedzą (Barney, 1995). Ich kumulacja pozwala na zbudowanie przewagi konkurencyjnej (Peteraf, 1993). Aby ją zmonetyzować, przed- siębiorstwo wykorzystuje swoje dynamiczne zdolności, dzięki którym aktywizuje potencjał wynikający ze swojej przewagi konkurencyjnej i wykorzystuje pojawiające się okazje rynkowe (Teece i in., 1997). Jak zatem widać, przesłanie RBV dla praktyki gospodarczej jest jasne: właściwie wszystko czego potrzeba do sukcesu, znajduje się wewnątrz organizacji, a głównym zadaniem menedżerskim jest przygotowanie jej do dynamicznego odbierania sygnałów rynkowych.

W SDL główny nacisk nie jest kładziony na wnętrze przedsiębiorstwa, ponieważ odbywa się w nim "jedynie” kreowanie potencjalnej wartości. Dopiero w otoczeniu przedsiębiorstwa tworzona jest wartość użyteczna $\mathrm{z}$ wykorzystaniem zasobów materialnych (operan(d) resources) i przede wszystkich w oparciu o zasoby czynnościowe (operan $(\mathrm{t})$ resources) rozumiane ogólnie jako: wiedza, technologia, umiejętności (Vargo, Lusch, 2004). Przy czym nie ma tutaj znaczenia, jaką standardową charakterystykę ma produkt/usługa, ale jakie korzyści odnosi ich odbiorca w toku korzystania z oferty (Dymitrowski, 2016). Stąd jedynie klient jest zawsze twórcą użytecznej wartości (Vargo, Lusch, 2008). Jeśli przedsiębiorstwo chciałoby ją współtworzyć, powinno zaproponować klientom pewne formy interakcji. Dzięki nim zapewnia ono sobie rolę w owym zewnętrznym procesie kreowania wartości przez swoich klientów, co prowadzi do wytworzenia wyższej (bardziej atrakcyjnej) wartości dzielonej następnie pomiędzy obie strony.

Spójrzmy teraz, jaki obraz powstanie, gdy nałożymy na siebie podstawowe założenia RBV i SDL. Sukces przedsiębiorstwa uzależniony jest od posiadania kluczowych, heterogenicznych zasobów (VRIO/operant resources) oraz dynamicznych zdolności. Te ostatnie można tłumaczyć jako umiejętność uczestniczenia w dialogu (procesie współtworzenia wartości), który nie jest w pełni zarządzany przez przedsiębiorstwo, ale zależy również od aktywności klienta (odbiorcy). Sens prowadzenia tego dialogu sprowadza się do tego, aby klient dzięki niemu mógł uczestniczyć $\mathrm{w}$ zindywidualizowanym procesie prowadzącym do wytworzenia wyższej wartości. Dla przedsiębiorstwa oznacza to z kolei możliwość skutecznej dyferencjacji oferty i jej odpowiednio wyższej wyceny. Stąd wynikają dwa zadania firmy: proaktywne angażowanie klientów z jednej strony i elastyczne odpowiadanie na zgłaszane przez nich potrzeby współpracy - z drugiej strony.

W tym kontekście dwa pytania pozostają jednak bez odpowiedzi: Jak w sposób planowy tworzyć kluczowe i heterogeniczne zasoby i dynamiczne zdolności? Jak przezwyciężać obojętność klientów i stać się dla nich istotnym partnerem $\mathrm{w}$ procesie tworzenia wartości? W poszukiwaniu odpowiedzi z pomocą przychodzi PRZP.

\section{Kluczowe i heterogeniczne zasoby w podejściu relacyjnym}

ak już powiedziano, kluczowe i heterogeniczne zasoby łączy się zwykle $z$ wiedzą posiadaną przez pracowników. Przy czym sam termin „wiedza” należy traktować bardziej jako metaforę niż zmienną ekonomiczną, choć 
można badać struktury organizacyjne i procesy prowadzące do powstawania wiedzy (Nonaka, Peltokorpi, 2006). Jako że mamy tu do czynienia przede wszystkim $\mathrm{z}$ ekosystemami ludzkimi, procesy tworzenia wiedzy opierają się na komunikacji (Mitręga, 2012). Nie mają one tradycyjnego, sekwencyjnego charakteru „zasoby na wejściu - zasoby na wyjściu”, ale przybierają raczej formę wielokierunkowych powiązań łączących pracowników i jednostki organizacyjne, które pojawiają się w toku wykonywania konkretnych zadań (Nonaka, Peltokorpi, 2006). Wyzwaniem stojącym przed zarządzającymi przedsiębiorstwem jest zatem stworzenie warunków organizacyjnych ułatwiających dyfuzję wiedzy, tak aby mogła ona być stale wykorzystywana i rozwijana.

W tym kontekście dbanie o „pracowników wiedzy” staje się zadaniem o strategicznym znaczeniu (Drucker, 2010). Jednakże innowacyjności, wysokiej motywacji i zaangażowania pracowników nie osiąga się za pomocą mechanistycznych działań tradycyjnych działów administracyjno-płacowych. Z pewnością nie w czasach dominacji pokolenia „Y”, które zgłasza znacznie bardziej wysublimowane oczekiwania wobec pracodawców niż poprzednie generacje (Eisner, 2005), nie toleruje ślepej dyscypliny i nie zdradza stałego przywiązania do jednego miejsca pracy (Smith, 2006). Stąd powstawanie kluczowych zasobów przedsiębiorstwa należy łączyć z zarządzaniem zasobami ludzkimi ukierunkowanym na indywidualne, podmiotowe podejście do pracowników (Deszczyński, 2016a). Systematyczne, indywidualistyczne podejście do zarządzania zasobami ludzkimi w przedsiębiorstwie można określić jako zarządzanie relacjami wewnętrznymi.

Znaczenie takiego podejścia w dziedzinie usług zostało po raz pierwszy zaakcentowane przez W.E. Hesketta, L.A. Sassera i J.L. Schlesingera w ich modelu łańcucha zysków (Service-Profit Chain) (1997). Zgodnie z tym modelem, właściwa sekwencja $\mathrm{w}$ procesie tworzenia wartości zaczyna się od autentycznego przywództwa liderów organizacji. Inspirują oni swoich pracowników do sięgania po ambitne cele. Wkładają równie wiele wysiłku w tworzenie sprzyjającego kreatywności środowiska pracy oraz poświęcają dużo czasu na selekcję, rozwój, nagradzanie i docenianie swoich pracowników. Dobre relacje kierownictwa firmy z pracownikami przekładają się na dobre relacje pomiędzy pracownikami i klientami. W efekcie również i ci ostatni są zadowoleni, wykazują się lojalnością i zaangażowaniem, co ma swoje odzwierciedlenie $\mathrm{w}$ wynikach finansowych przedsiębiorstwa. Stąd, zgodnie z modelem łańcucha zysków, pełny obraz działania przedsiębiorstwa odzwierciedla generowana przez nie wartość dla klientów, pracowników i właścicieli (akcjonariuszy), a także redukcja kosztów (Payne, Frow, 2013).

Przenosząc ideę zarządzania relacjami wewnętrznymi (z pracownikami) na grunt RBV i SDL, otrzymujemy następujące zależności. Aby stworzyć atrakcyjną ofertę dla klientów zewnętrznych, proces kreowania potencjalnej wartości, który ma miejsce $\mathrm{w}$ przedsiębiorstwie, musi zostać zbudowany w oparciu o kluczowe i heterogeniczne zasoby. Jednak nawet jeśli takowe w przedsiębiorstwie występują, nie oznacza to, że zostaną wykorzystane. Pozostają one w części lub w całości ukryte w pracownikach, chyba że zostaną aktywowane poprzez stosowne działania $\mathrm{z}$ zakresu zarządzania zasobami ludzkimi (np. docenianie indywidualnych umiejętności, preferencji i ambicji pracowników) i dzięki generalnemu partnerstwu pomiędzy menedżerami i pracownikami (efektywna kultura organizacyjna). Stąd aktywizacja kluczowych zasobów wymaga, aby proces tworzenia potencjalnej wartości przybrał jednocześnie formę wewnętrznego procesu współkreowania wartości atrakcyjnej dla samych pracowników (Grace, Iacono, 2015, s. 560). W rezultacie pracownicy otrzymują szansę na osiągnięcie równowagi pomiędzy pracą a życiem prywatnym oraz realizacji swoich potrzeb w pełnym zakresie złożoności istoty ludzkiej. Tylko w takim przypadku praca nie jest postrzegana jako jednowymiarowa transakcja: czas vs. płaca.

Tego rodzaju transakcyjne postrzeganie miejsca pracy zachęca pracowników do przeciętności. Im bowiem mniej wysiłku włożą w wykonywanie pracy, tym lepszy będzie ich osobisty wynik tej transakcji. Stąd przewaga konkurencyjna oparta na kluczowych i heterogenicznych zasobach możliwa jest tylko wówczas, gdy pracownicy uczestniczą w wewnętrznym procesie tworzenia potencjalnej wartości, jednocześnie współtworząc zindywidualizowaną wartość dla siebie. Podobnie jak w przypadku klientów rezultatem jest wykreowanie większej wartości, co stanowi bodziec dla pracowników do większego zaangażowania w pracę, np. poprzez szczególną dbałość o wypełnianie standardów jakościowych oraz wychodzenie $\mathrm{z}$ innowacyjnymi inicjatywami. Dla przedsiębiorstwa oznacza to konieczność dbania zarówno o satysfakcję klientów, jak i pracowników, co podnosi rangę zarządzania relacjami wewnętrznymi do tego samego poziomu co zarządzanie relacjami z klientami.

\section{Dynamiczne zdolności w podejściu relacyjnym}

$\mathrm{K}$ onsekwencją stwierdzenia, że dynamiczne zdolności przedsiębiorstwa można tłumaczyć jako posiadanie przez nie umiejętności do współtworzenia wartości, jest potrzeba zbudowania przez firmę platformy współpracy $\mathrm{z}$ jej wewnętrznymi i zewnętrznymi interesariuszami (Małys, 2018). Jest to założenie podnoszone również w PRZP. Przyjmuje się tu jednocześnie, że logicznym następstwem współpracy jest powstawanie zasobów relacyjnych (Dymitrowski, Soniewicki, 2015). Są one definiowane jako specjalna klasa zasobów niematerialnych, tworzonych w wyniku interakcji prowadzących do powstawania użytecznej wiedzy oraz pozytywnych powiązań z przedsiębiorstwem i jego pracownikami (Chen i in., 2011; Deszczyński, 2014). W tym kontekście zasoby relacyjne stanowią efekt kumulacji wielostronnych doświadczeń, zaufania, zaangażowania i procesów uczenia się (Zdziarski, 2016).

Aktualny stan zasobów relacyjnych przedsiębiorstwa można nazwać jego kapitałem relacyjnym. Zgodnie z definicją zasobów relacyjnych, kapitał ten powstaje w wyniku prowadzenia dialogu $\mathrm{z}$ interesariuszami przedsiębiorstwa, a jest nieaktywny $\mathrm{w}$ przypadku braku takiego dialogu (Gummesson, 2004). Stąd, jeśli zasoby relacyjne powstają w wyniku procesu współtworzenia przez przedsiębiorstwo 
wartości z jego pracownikami i klientami, dynamiczne zdolności uwidaczniają się $\mathrm{w}$ sposobie, $\mathrm{w}$ jakim przedsiębiorstwo zarządza relacjami wewnętrznymi (procesem współkreowania wartości przez pracowników) oraz relacjami zewnętrznymi (procesem współkreowania wartości przez klientów). Podstawowe bliskoznaczne terminy występujące jednocześnie $\mathrm{w}$ RBV, SDL i PRZP zestawiono w tabeli 1.

Jak można zauważyć, terminy wprowadzone w RBV mają charakter dość ogólny. Określenia używane w SDL i PRZP w większym stopniu operacjonalizują przedmiotowe zjawiska, zdradzając specyficzne dla obu koncepcji akcenty. Ta formalna różnorodność taksonomiczna na gruncie aksjologicznym nie ma jednak aż tak fundamentalnego znaczenia, aby nie można było wskazać występujących pomiędzy zestawionymi terminami logicznych powiązań. Dla zachowania jasności i kompatybilności z publikacjami angielskojęzycznymi, w nawiasach podano najczęściej występujące w literaturze oryginalne terminy.

\section{Przełamywanie obojętności klientów przez znaczące interakcje}

$\mathbf{Z}$ wyczajową praktyką biznesową w stosowaniu PRZP było i jest objęcie zarządzaniem jedynie ograniczonej liczby punktów styku / interakcji z interesariuszami. Obecnie jednak widoczne staje się również dążenie do objęcia zarządzaniem relacji nawiązywanych przez wszystkie funkcyjne jednostki przedsiębiorstwa, zarówno te działające zwykle w ukryciu, jak i te bezpośrednio współpracujące z klientami i pozostałymi interesariuszami, np. dostawcami (Sheth, 2017). Rozwijane dzięki osobistym, telefonicznym i wirtualnym kontaktom relacje, mają kluczowe znaczenie dla procesu współkreowania rozumianego nie w sposób transakcyjnej wymiany wartości (value-in-exchange), ale współpracy zorientowanej na wspólne wytworzenie wartości w trakcie korzystania z oferty przez klienta (value-inuse). S.L. Vargo i R.F. Lusch (2016, s. 9) wskazują, co prawda, że obok bezpośrednich interakcji platforma dialogu może mieć również charakter instytucjonalny, nie wyłączając komunikacji za pomocą produktu fizycznego. Jednak nawet zaawansowane technicznie urządzenie (np. tablet lub urządzenie wykorzystujące Internet Rzeczy) bez strategii wielokanałowego dialogu nie zapewni uczestnictwa klientów w projektowaniu produktu lub jego koprodukcji - podstawowych aktywności występujących w procesie współkreowania wartości (Dong, 2015, s. 498). Co więcej, zgodnie z dorobkiem badaczy sieci sieci społecznych, stopień współzależności partnerów relacji jest bezpośrednio odzwierciedlany w ilości kanałów komunikacji, jakie stosują do jej podtrzymania (Haythornthwaite, 2005). Stąd też można sformułować wniosek, że prawdopodobieństwo współtworzenia wartości jest tym większe, im więcej możliwości wielostronnych interakcji przedsiębiorstwo proponuje klientom na każdym $\mathrm{z}$ etapów jej powstawania. $\mathrm{Na}$ gotowość do współtworzenia wartości z przedsiębiorstwem ma jednak również wpływ charakter oferty i rynku. W niektórych branżach, takich jak konsumpcyjne produkty szybkozbywalne, przedsiębiorstwa muszą się zmagać z immanentną anonimowością rynku. Jedyną odpowiedzią na tego typu wyzwanie jest zajęcie znaczącego miejsca w świadomości klientów.

Pozycję znaczącego w oczach klienta partnera można uzyskać dzięki zapewnieniu wysokiej jakości oferty i korespondującemu z nią postrzeganiu marki. Opanowanie innych tradycyjnych narzędzi marketingowych, takich jak strategia „push” i współpraca $z$ pośrednikami, również może przynosić pożądane rezultaty, w szczególności w sektorze B2C. Narzędzia te, choć istotne, sprowadzają jednak komunikację do modelu jednostronnego nadawania. Skoro współkreowanie wartości to proces relacyjny oparty na dialogu, wymaga ono jednak komunikacji dwustronnej. W tym kontekście jeszcze większego znaczenia nabiera troska o stworzenie platformy dialogu, co oznacza konieczność koordynacji wielu bezpośrednich i wspieranych poprzez technologie informatyczne kanałów komunikacji, tak aby zapewnić warunki do powstania pomiędzy klientami a przedsiębiorstwem emocjonalnych więzi i wymiany wiedzy (Payne i in., 2009).

Ta konieczność kolejny raz zwraca naszą uwagę na pracowników. Zarządzając relacjami wewnętrznymi i zapewniając pracownikom udział w procesie współtworzenia wartości, przedsiębiorstwo zyskuje trwale zaangażowanych członków organizacji szkolonych i zmotywowanych do stawania się wartościowymi partnerami relacji zewnętrznych. Ich aktywne podejście zmienia standardowe sytuacje obsługowe w elastycznie dostosowywane do indywidualnej sytuacji doświadczenia, których nie sposób wcześniej zaprojektować. Oznacza to dla przedsiębiorstw częściową utratę kontroli nad przebiegiem interakcji, która jednak zostaje zastąpiona przez znacznie lepsze narzędzie: samokontrolę. Zdejmuje to też z barków kierownictwa przedsiębiorstwa (w gruncie rzeczy) niemożliwe do wykonania zadanie scentralizowanego zaplanowania rzeczywistej strategii marketingowej 1-do-1. O jej treści stanowi bowiem elastyczność kontaktów klienta i pracownika, którzy zostali uprawomocnieni do współużytkowania zasobów udostępnianych przez przedsiębiorstwo w optymalny dla siebie sposób. Otwiera to drogę nie tylko do

Tabela 1. Podstawowe terminy występujące w RBV, SDL i PRZP

\begin{tabular}{|l|l|l|}
\hline \multicolumn{1}{|c|}{ RBV } & \multicolumn{1}{|c|}{ SDL } & \multicolumn{1}{c|}{ PRZP } \\
\hline $\begin{array}{l}\text { kluczowe, heterogeniczne zasoby (VRIO } \\
\text { resources) }\end{array}$ & zasoby czynnościowe (operant resources) & zasoby relacyjne (relationship assets) \\
\hline dynamiczne zdolności (dynamic capabilities) & współkreowanie wartości (value co-creation) & $\begin{array}{l}\text { zarządzanie relacjami (relationship } \\
\text { management) }\end{array}$ \\
\hline
\end{tabular}

Źródto: opracowanie wtasne 
znaczących interakcji, ale do powstania całego ekosystemu zbudowanego wokół klienta (customer-dominant logic) (Heinonen, Strandvik, 2015).

Zarządzanie relacjami oznacza zatem czynienie interakcji najbardziej znaczącymi, jak to tylko jest możliwe. Celem jest tu zazębienie uprzednio rozdzielnych procesów tworzenia potencjalnej i rzeczywistej wartości poprzez proaktywne zapraszanie klientów do wzięcia udziału w procesie wewnątrzorganizacyjnym i gotowość do podjęcia roli w indywidualnych procesach kreowania wartości przez klientów. Może się to dziać poprzez współpracę przy zaprojektowaniu nowego produktu lub usługi, zmiany w dotychczasowych wymaganiach funkcjonalnych, weryfikację procedur logistycznych i komunikacyjnych oraz stworzenie u klientów przeświadczenia, że ich współpraca jest mile widziana gdziekolwiek ma to dla nich znaczenie (Minkiewicz i in., 2016).

Mimo to również ukierunkowanie na współtworzenie wartości ma swoje granice. Klienci powinni być bowiem gotowi do poniesienia dodatkowych kosztów indywidualizacji oferty, przy czym różnica pomiędzy dodatkową wspólnie wytworzoną wartością a kosztami z tym związanymi musi być odpowiednio duża. Oznacza to, iż strategia relacyjna wspierająca procesy współtworzenia wartości zgodnie $\mathrm{z}$ koncepcją logiki usługowej powinna być realistyczna i selektywna (Deszczyński, 2016b). Zatem przedsiębiorstwo nie powinno przyjmować nastawienia na współtworzenie wartości za wszelką cenę, ponieważ nie każda relacja $\mathrm{z}$ klientem ma potencjał do tego, aby wygenerować tą drogą dodatkową wartość dla obu stron.

Mając to na uwadze, przedsiębiorstwo winno lepiej wykorzystywać potencjał do współtworzenia wartości takich interakcji, które już obecnie mają miejsce. To, w jaki sposób pracownicy pierwszego kontaktu informują, doradzają i zbierają opinie klientów, ma bowiem dla odbiorców kluczowe znaczenie. Dzieje się tak przede wszystkim na etapie zbierania informacji o dostępnych opcjach wyboru lub po zakupie, gdy klienci wymagają wsparcia, aby móc $\mathrm{w}$ pełni korzystać $\mathrm{z}$ dobrodziejstw zakupionych produktów i usług (Celuch i in., 2015).

Gotowość do udzielania informacji, empatia i uprzejmość to cechy pracowników przydatne również w kontaktach online (Zhang i in., 2018). Dotyczy to szczególnie budowania i rozwoju skupionych wokół marki społeczności internetowych. Stąd odpowiedzialność za utrzymanie właściwych relacji z fanami w mediach społecznościowych nie może podlegać outsourcingowi. Przeciwnie, proces ten powinien angażować i inspirować cały zespół pracowniczy (Kao i in., 2016). Strona, która w interakcji nie wychodzi poza przyjęte w korporacji „formułki”, $\mathrm{z}$ natury rzeczy nie jest bowiem wartościowym partnerem dialogu ani w świecie realnym, ani w wirtualnym.

\section{Podsumowanie}

ak wykazano, RBV, SDL i PRZP to koncepcje, które w dużym stopniu się uzupełniają. RBV kładzie fundamenty w poszukiwaniu źródeł tworzenia wartości przez przedsiębiorstwo. Jego podstawowe założenia (kluczowe i heterogeniczne zasoby przyczyniają się do osiągniecia przewagi konkurencyjnej w wybranym obszarze, a dynamiczne zdolności umożliwiają jej monetyzację) można uzupełnić o kolejne zaczerpnięte $\mathrm{z}$ koncepcji logiki usługowej (dynamiczne zdolności uzewnętrzniają się w umiejętności współtworzenia wartości z klientami). To, w czym na pierwszy rzut oka RBV i SDL nie są zgodne, to źródło pochodzenia wartości. Na gruncie zasobowym przyjmuje się, że wartość pochodzi z wnętrza przedsiębiorstwa, a według logiki usługowej centralne miejsce $\mathrm{w}$ tworzeniu wartości zajmuje proces, którego właścicielem jest nie przedsiębiorstwo a klient.

PRZP stanowi jednak pomost pomiędzy tymi teoriami. Główne elementy SDL (współtworzenie wartości, współpraca, współwykorzystywanie zasobów, wielostronna komunikacja, sieci oparte o kreowanie wartości) mają charakter relacyjny. $\mathrm{Z}$ kolei relacje $\mathrm{z}$ natury rzeczy budowane są na drodze nieodłącznych w usługach: wymiany i partycypacji. Tak dynamiczny układ wymaga stałych interakcji, które można koordynować za pomocą zarządzania relacjami wewnętrznymi i zewnętrznymi. Celem zarządzania relacjami wewnętrznymi powinno być współtworzenie wartości z pracownikami, a celem zarządzania relacjami zewnętrznymi współtworzenie wartości z klientami. W obu przypadkach przekłada się to na rozwój kluczowych i heterogenicznych zasobów i odzwierciedla zdolności dynamiczne przedsiębiorstwa. Wspólną klasą kluczowych zasobów, jakie powstają $\mathrm{w}$ ramach zarządzania relacjami wewnętrznymi i zewnętrznymi, są zasoby relacyjne. Pozostają one czasowo do dyspozycji przedsiębiorstwa i ostatecznie decydują o uzyskaniu przewagi konkurencyjnej i jej monetyzacji. W konsekwencji powodzenie zarządzania relacjami zewnętrznymi uzależnione jest od zarządzania relacjami wewnętrznymi, ponieważ to od zaangażowania pracowników zależy, czy

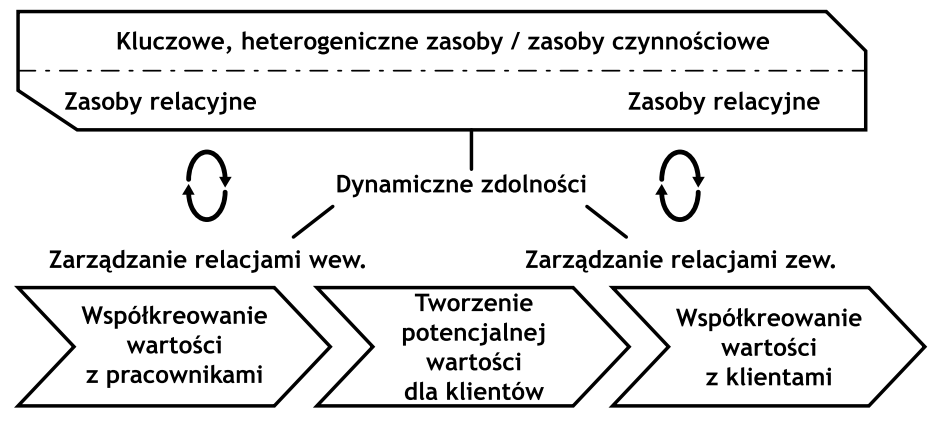

Rys. 1. Model funkcjonowania firmy w oparciu o RBV, SDL i PRZP

Źródto: opracowanie własne 
interakcje $\mathrm{z}$ przedsiębiorstwem zaistnieją $\mathrm{w}$ świadomości klientów jako znaczące. Stąd wniosek, iż dzieląc i współtworząc więcej wartości z pracownikami, przedsiębiorstwo generuje więcej wartości dla pozostałych interesariuszy, z klientami i właścicielami firmy na czele. Graficzne przedstawienie opisanych współzależności zawiera rysunek 1.

Podsumowując, należy wyrazić nadzieję, że artykuł ten przyczyni się do wzbogacenia dyskusji na gruncie teorii firm, szczególnie w zakresie endogenicznych źródeł pochodzenia przewagi konkurencyjnej i rynkowego powodzenia przedsiębiorstw. Może on również stanowić przyczynek do próby formułowania wytycznych w warstwie projektowo-wdrożeniowej, których głównym punktem odniesienia będzie relacyjne podejście w zarządzaniu zasobami ludzkimi. Z pewnością taką dyskusję wzbogaciłaby empiryczna weryfikacja głównych założeń zwartych w artykule, co jest zamiarem autora $\mathrm{w}$ toku realizacji grantu badawczego poświęconego dojrzałości przedsiębiorstw w zarządzaniu relacjami.

\section{dr Bartosz Deszczyński \\ Uniwersytet Ekonomiczny w Poznaniu \\ Wydział Gospodarki Międzynarodowej \\ ORCID: 0000-0001-6798-7952 \\ e-mail: bartosz.deszczynski@ue.poznan.pl}

\section{Przypis}

1) Artykuł przygotowano w ramach realizacji projektu badawczego 2015/19/D/HS4/01956 finansowanego przez Narodowe Centrum Nauki.

\section{Bibliografia}

[1] Barney J. (1991), Firm Resources and Sustained Competitive Advantage, „Journal of Management”, Vol. 17, No. 1, http:// dx.doi.org/10.1177/014920639101700108.

[2] Barney J. (1995), Looking inside for Competitive Advantage, „The Academy of Management Executive (1993-2005), Vol. 9, No. 4, pp. 49-61.

[3] Bratnicki M. (2012), Przedsiębiorcze zdolności dynamiczne jako źródło trwałej, wysokiej efektywności przedsiębiorstwa, [w:] H. Jagoda, J. Lichtarski (red.), Kierunki i dylematy rozwoju nauki i praktyki zarządzania przedsiębiorstwem, Wydawnictwo Uniwersytetu Ekonomicznego we Wrocławiu, Wrocław, s. 37-45.

[4] Celuch K., Robinson N.M., Walsh A.M. (2015), A Framework for Encouraging Retail Customer Feedback, ,Journal of Services Marketing", Vol. 29, No. 4, pp. 280-292, https://doi. org/10.1108/JSM-02-2014-0062.

[5] Chen T.-Y., Yeh T.-L., Yeh H.Ch. (2011), Trust-Building Mechanisms and Relationship Capital, „Journal of Relationship Marketing", Vol. 10, No. 3, pp. 113-144, doi: 10.1080/15332667.2011.596471.

[6] Czakon W. (2010), Zasobowa teoria firmy w krzywym zwierciadle, „Przegląd Organizacji”, Nr 4, s. 8-12.

[7] Deszczyński B. (2014), Zasoby relacyjne - konceptualizacja pojęcia $w$ świetle zasobowej teorii przedsiębiorstwa, „Studia Oeconomica Posnaniensia”, Nr 2(11), s. 25-44.
[8] Deszczyński B. (2016), The Maturity of Corporate Relationship Management, „Gospodarka Narodowa”, Nr 3(283), s. 73-104.

[9] Deszczyński B. (2016), Upodmiotowienie pracowników jako element przewagi konkurencyjnej $w$ organizacjach ukierunkowanych na zarzadzanie relacjami, „Studia Ekonomiczne", Nr 255, s. 280-288.

[10] Dong B. (2015), How a Customer Participates Matters: „I am Producing” versus „I am Designing”, „Journal of Services Marketing", Vol. 29, No. 6/7, pp. 498-510, https://doi. org/10.1108/JSM-01-2015-0020.

[11] Dymitrowski A. (2016), The Nature of Business Model Innovation, [in:] B. Borusiak, M. Lewicki (eds.), Innovation Management: Research Aspects, Bugucki Wydawnictwo Naukowe, Poznań, s. 19-28.

[12] Dymitrowski A., Soniewicki M. (2015), Companies Cooperation in the Internationalization Process and Their Competitive Advantage, 31st IMP Conference in Kolding, Denmark.

[13] Drucker P.F. (2010), Classic Drucker, MT Biznes, Warszawa.

[14] Eisner S.P. (2005), Managing Generation Y, „SAM Advanced Management Journal", Vol. 70, No. 4.

[15] Gordon I.H. (2013), Managing the New Customer Relationship, Strategies to Engage the Social Customer and Build Lasting Value, John Wiley \& Sons, New York.

[16] Grace D., Iacono J.L (2015), Value Creation: An Internal Customers' Perspective, „Journal of Services Marketing”, Vol. 29, No. 6/7, pp. 560-570, https://doi.org/10.1108/JSM09-2014-0311.

[17] Grönroos C. (2015), Service Management and Marketing: Managing the Service Profit Logic, 4th ed., John Wiley \& Sons, Chichester.

[18] Grönroos C. (2017), Relationship Marketing Readiness: Theoretical Background and Measurement Directions, „Journal of Services Marketing", Vol. 31, No. 3, pp. 218-225, https:// doi.org/10.1108/JSM-02-2017-0056.

[19] Grönroos C., Voima P. (2013), Critical Service Logic: Making Sense of Value Creation and Co-creation, ,Journal of the Academy of Marketing Science”, Vol. 41, No. 2, pp. 133-150.

[20] Gummesson E. (2004), Return on Relationships (ROR): the Value of Relationship Marketing and CRM in Business-to-business Contexts, "Journal of Business \& Industrial Marketing”, Vol. 19, No. 2, pp. 136-148, doi:10.1108/08858620410524016.

[21] Gummesson E. (2017), From Relationship Marketing to Total Relationship Marketing and Beyond, „Journal of Services Marketing", Vol. 31, Iss. 1, pp. 16-19, http://dx.doi. org/10.1108/JSM-11-2016-0398.

[22] Håkansson H., Ford D., Gadde L.-E., Snehota I., Waluszewski A. (2009), Business in Networks, John Wiley and Sons, Chichester.

[23] Hamel G. (2002), Leading the Revolution, Plume, Boston.

[24] Haythornthwaite C. (2005), Social Networks and Internet Connectivity Effects. Information, "Communication \& Society, Vol. 8, No. 2, pp. 125-147.

[25] Heinonen K., Strandvik T. (2015), Customer-dominant Logic: Foundations and Implications, ,Journal of Services Marketing”, Vol. 29, No. 6/7, pp. 472-484, https://doi.org/10.1108/JSM02-2015-0096. 
[26] Heskett J.L., Sasser W.E., Schlesinger L. (1997), The Service Profit Chain, Free Press, New York.

[27] Kao T.-Y., Yang M.-H., Ben Wu J.-T., Cheng Y.-Y. (2016), Co-creating Value with Consumers through Social Media, "Journal of Services Marketing", Vol. 30, No. 2, pp. 141-151, https://doi.org/10.1108/JSM-03-2014-0112.

[28] Krupski R. (2012), Rozwój szkoły zasobów zarządzania strategicznego, „Przegląd Organizacji”, Nr 4, s. 3-7.

[29] Lovelock C., Patterson P. (2015), Services Marketing, Pearson Australia, Melbourne.

[30] Małys Ł. (2018), Actors in Business Relationships, [in:] K. Fonfara, Ł. Małys, M. Ratajczak-Mrozek (eds.), The Internationalisation Maturity of the Firm. A Business Relationships Perspectiv, Cambridge Scholars Publishing, Newcastle upon Tyne, pp. 17-21.

[31] Minkiewicz J., Bridson K., Evans J. (2016), Co-production of Service Experiences: Insights from the Cultural Sector, „Journal of Services Marketing", Vol. 3, No. 7, pp. 749-761, https:// doi.org/10.1108/JSM-04-2015-0156.

[32] Mitręga M. (2012), Network Partner Knowledge and Internal Relationships Influencing Customer Relationship Quality and Company Performance, „Journal of Business \& Industrial Marketing", Vol. 27, No. 6, pp. 486-496, https://doi. org/10.1108/08858621211251488.

[33] Moss Kanter R. (2011), Zoom in, Zoom out, „Harvard Business Review", Vol. 89, No. 3, pp. 112-116.

[34] Nonaka I., Peltokorpi V. (2006), Objectivity and Subjectivity in Knowledge Management: A Review of 20 Top Articles, „Knowledge and Process Management", Vol. 13, No. 2, pp. 73-82.

[35] Obłój K. (2007), Pułapki teoretyczne zasobowej teorii strategii, „Przegląd Organizacji”, Nr 5, s. 7-10.

[36] Payne A., Frow P. (2013), Strategic Customer Management. Integrating Relationship Marketing and CRM, Cambridge University Press, Cambridge.

[37] Payne A., Frow P. (2017), Relationship Marketing: Looking Backwards Towards the Future, „Journal of Services Marketing", Vol. 31, Iss. 1, pp. 1-8, http://dx.doi.org/10.1108/JSM11-2016-0380.

[38] Payne A., Storbacka K., Frow P., Knox S. (2009), Co-creating Brands: Diagnosing and Designing the Relationship Experience, „Journal of Business Research”, Vol. 62, No. 3, pp. 379-389.

[39] Peteraf M.A. (1993), The Cornerstones of Competitive Advantage: a Resource Based View, „Strategic Management Journal”, Vol. 14, pp. 179-191.

[40] Porter M.E. (1979), How Competitive Forces Shape Strategy, „Harvard Business Review”, Vol. 57, No. 2, pp. 137-145.

[41] Ray G., Barney J.B., Muhanna W.A. (2004), Capabilities, Business Processes, and Competitive Advantage: Choosing the Dependent Variable in Empirical Tests of the Resourcebased View, „Strategic Management Journal”, Vol. 25, No. 1, pp. 23-37.

[42] Sheth J. (2017), Revitalizing Relationship Marketing, ,Journal of Services Marketing", Vol. 31, No. 1, pp. 6-10, https://doi. org/10.1108/JSM-11-2016-0397.

[43] Smith J. (2006), Empowerment. Jak zwiększyć zaangażowanie pracowników, Helion, Gliwice.

[44] Teece D.J., Pisano G., Shuen A. (1997), Dynamic Capabilities and Strategic Management, „Strategic Management Journal”, Vol. 18, No. 7, pp. 509-533.
[45] Vargo S.L., Lusch R.F. (2004), Evolving to a New Dominant Logic for Marketing, ,Journal of Marketing", Vol. 68 (January), pp. 1-17.

[46] Vargo S.L., Lusch R.F. (2008), Service-Dominant Logic: Continuing the Evolution, "Journal of the Academy of Marketing Science", Vol. 36, pp. 1-10, http://dx.doi.org/10.1007/s11747007-0069-6.

[47] Vargo S.L., Lusch R.F. (2016), Institutions and Axioms: An Extension and Update of Service-dominant Logic, „Journal of the Academy of Marketing Science", Vol. 44, No. 5, pp. 5-23, https://doi.org/10.1007/s11747-015-0456-3.

[48] Vargo S.L., Lusch R.F. (2017), Service-dominant Logic 2025, „International Journal of Research in Marketing”, Vol. 34, No. 1, pp. 46-67.

[49] Wernerfelt B. (2016), Adaptation, Specialization, and the Theory of the Firm, Foundations of the Resource-Based View, Cambridge University Press, Cambridge.

[50] Zaefarian G., Forkmann S., Mitręga M., Henneberg S.C. (2017), A Capability Perspective on Relationship Ending and Its Impact on Product Innovation Success and Firm Performance, „Long Range Planning”, Vol. 50, No. 2, pp. 184-199, https://doi. org/10.1016/j.lrp.2015.12.023.

[51] Zakrzewska-Bielawska A. (2013), Zasobowe uwarunkowania koopetycji w przedsiębiorstwach high-tech, „Przegląd Organizacji”, Nr 2, s. 3-8.

[52] Zhang T., Lu C., Torres E., Chen P.-J. (2018), Engaging Customers in Value Co-creation or Co-destruction Online, „Journal of Services Marketing", Vol. 32, No. 1, pp. 57-69, https://doi. org/10.1108/JSM-01-2017-0027.

[53] Zdziarski M. (2016), Nurt sieciowy - W kierunku nowego paradygmatu zarzadzania? Prace Naukowe Uniwersytetu Ekonomicznego we Wrocławiu, Nr 421, s. 657-668, DOI: 10.15611/ pn.2016.421.52.

\section{Resource-based View and Service-dominant Logic in Relationship Management Approach}

\section{Summary}

Resource-Based View (RBV) has a leading position in the strategic management research. However, it is by far not a complete theory. One of its constraints is the fact that it concentrates on preliminary conditions for achieving a competitive advantage and protecting it, but it fails to articulate how to formulate and implement a workable strategy. Service-Dominant Logic (SDL) has a leading position in the services marketing literature. Additionally, it also faces problems in transferring theory into the managerial practice. The purpose of this paper is a conceptual identification of how both concepts can reinforce each other through the mediation of Relationship Management (RM). The paper emphasises the need to study RBV and SDL through the lenses of RM in search for a possible mid-range theory of a firm with focus on managerial planning and actions.

\section{Keywords}

Resource-Based View (RBV), Service-Dominant Logic (SDL), relationship management 